\title{
OPERATIONAL EXPERIENCE OF GNSS RECEIVERS WITH CHIP SCALE ATOMIC CLOCKS FOR BASELINE MEASUREMENTS
}

\author{
Alexander P. KARPIK ${ }^{1^{*}}$, Nikolay S. KOSAREV ${ }^{1}$, Konstantin M. ANTONOVICH ${ }^{1}$, \\ Irina G. GANAGINA ${ }^{1}$, Vladimir Yu. TIMOFEEV ${ }^{2}$ \\ ${ }^{1}$ Siberian State University of Geosystems and Technologies, Novosibirsk, Russia \\ ${ }^{2}$ Trofimuk Institute of Petroleum Geology and Geophysics, Novosibirsk, Russia
}

Received 19 July 2018; accepted 15 November 2018

\begin{abstract}
Currently, one of the topical issues of improving GLONASS system is modernization of its uniformity measurement equipment, including RF measurement equipment and electronic length measurement equipment. To this end, at the Spatial Reference Proving Ground of theSiberian State University of Geosystems and Technologies (SSUGT), the authors of this article carried out a successful experiment to measure a short GNSS baseline by receivers equipped with Chip Scale Atomic Clocks (CSACs) with instability of $10^{-11}$ showed that the mean deviation between the slant distance (D) measured using GNSS receivers connected to CSACs and their certified value varied in the range of $0.1-2.5 \mathrm{~mm}$, with the average value of $0.9 \mathrm{~mm}$. The mean deviation obtained using GNSS geodetic receivers not connected to CSAC and their certified value made up $9.4 \mathrm{~mm}$.

The obtained experimental results suggest that substitution of quartz frequency generators with temperature compensation used in geodetic GNSS receivers for Chip Scale Atomic Clocks in any metrological or verification kit increases accuracy and reliability of short baselines measurements results, which highly perspective in view of development of techniques for creating reference baselines with a reproduction error of unit length of about $1 \mathrm{~mm}$ per $1 \mathrm{~km}$.

The above-mentioned experiment opens up new horizons for the use of Chip Scale Atomic Clocks in such fields of science as metrological support of geodetic equipment, geodesy, etc.
\end{abstract}

Keywords: GNSS, receiver, Chip Scale Atomic Clock, accuracy of measurements.

\section{Introduction}

Obtaining objective and qualitative geospatial data is one of the key factors shaping the appearance of the digital economy of the Russian Federation, aimed at increasing the country's competitiveness, the quality of life its citizens, ensuring economic growth and national sovereignty (Programma "Tsifrovaya ekonomika Rossiyskoy Federatsii", 2017).

The quality and objectivity of this data in the Russian Federation is regulated by the Federal Law No. 102 of August 26, 2008 "On ensuring the uniformity of measurements", which establishes mandatory metrological requirements ensuring objective, reliable and comparable measurement results used to protect life and health of citizens, environmental protection, ensuring the defence and security of the state, including economic security (Federal'nyy Zakon No. 102..., 2008; Sil'vestrov, Mazurkevich, Vernitskiy, Sokolov, \& Golub, 2016).
The provisions of the Federal Law No. 102 "On ensuring the uniformity of measurements" apply to ensuring the uniformity of the measuring equipment used in geodetic and cartographic activities. Modern measuring equipment includes, inter alia, the GNSS satellite receivers using GLONASS signals; the former have to be verified and tested to obtain pattern approval certificates.

Nowadays, one of the urgent issues of improving GLONASS system is the modernization of equipment ensuring the uniformity of measurements, including RF and electronic length measurement equipment (Shchipunov et al., 2015). In the context of this issue, there are a number of ongoing research projects to create and improve standard complexes that ensure the uniformity of length measurement (Sil'vestrov et al., 2016; Shchipunov et al., 2015; Denisenko et al., 2016).

In our opinion, among the promising areas for improving reference complexes, we can refer to the use of Chip Scale Atomic Clocks (CSACs) in modern GNSS re-

*Corresponding author. E-mail: higher.education2017@yandex.ru 
ceivers, which allow improving the quality, validity, and reliability of the results of field satellite measurements (Kitching, 2007; Shkel, 2011; Chan, Joerger, Khanafseh, Pervan, \& Jakubov, 2014; Antonovich, Kosarev, \& Lipatnikov, 2014; Antonovich \& Kosarev, 2014; Beard \& Senior, 2017).

The experiment aims at studying the possibility of using GNSS receivers with CSACs with relative instability of $10^{-11}$ to improve standard complexes, which ensure the uniformity of length measurement.

\section{Materials and methods}

\subsection{Theoretical part}

Rationale for the application of CSACs to improve Standard complexes that ensure the uniformity of length measurement.

Consider increments of phase pseudoranges $\Delta F$ between epochs $t$ and $t+\Delta t$, provided that integer ambiguity is resolved (Antonovich \& Kosarev, 2012):

$$
\begin{aligned}
& \Delta F(t)=F(t+\Delta t)-F(t)=\Delta \rho(t, t-\tau)+\Delta t \cdot A 1_{r}+\Delta \Sigma, \\
& A 1_{r}=0+\omega_{t},
\end{aligned}
$$

where $\Delta \rho(t, t-\tau)$ are the increments of geometric distances between the receiver and the satellite; $A 1_{r}$ is the rate of clock of GNSS receiver, which generates a random process such as "white noise" $\left(\omega_{t}\right)$ (Enric, Calero, \& Parés, 2017; Krawinkel \& Schön, 2015); $\Delta \Sigma$ is the total increment of errors due to atmospheric delays, multipath effect, and measurement noise.

The error due to the receiver clock instability $\delta A 1$ in a time $D t$, is estimated by the formula

$$
\delta \Delta F=c \delta A 1_{r} \cdot \Delta t
$$

where $c$ is the speed of light, $c \approx 3 \times 10^{8} \mathrm{~m} / \mathrm{s}$.

The relative clock instability for quartz frequency oscillators with temperature compensation used in GNSS geodesic receivers with clock instability of $10^{-9}$ (Enric et al., 2017; Krawinkel \& Schön, 2015 ) that at surveillance sam- ple rate $D t=15 \mathrm{sec}$ will lead to an error in the increment of the phase pseudoranges $\delta \Delta F=4.5 \mathrm{~m}$ (linear measure). For CSACs with relative clock instability of $10^{-12}$ (Enric et al., 2017; Krawinkel \& Schön, 2015), the corresponding error is reduced by three orders of magnitude, to a value equal to $4.5 \mathrm{~mm}$, which is a prerequisite for increasing the accuracy of baseline measurements.

Other positive effects of CSACs in GNSS receivers include improvement of the navigation solution, increasing the availability of the solution, improving signal capture, reducing multipath effect, eliminating interference, and spoofing detection (Kitching, 2007; Shkel, 2011; Chan, Joerger, Khanafseh, Pervan, \& Jakubov, 2014; Antonovich, Kosarev, \& Lipatnikov, 2014; Antonovich \& Kosarev, 2014; Beard \& Senior, 2017; Enric et al., 2017; Krawinkel \& Schön, 2015).

\subsection{Practical part}

At present, Standard Complex of the Siberian State University of Geosystems and Technologies (SSUGT) is a Geodetic Standard Proving Ground (GSPG) (Figure 1) where metrological verifications of GNSS satellite equipment and research projects on geospatial technologies have been conducted since 1997 (Surnin, 2004; Karpik, Seredovich, Antonovich, \& Kulikova, 2010; Antonovich \& Kulikova, 2017).

The considered GSPG is a second-order geodetic network. The mean-square error (MSE) for distance measured by the GSPG network is characterized by the value of $\Delta= \pm\left(2+0.5 \times 10^{-6} D\right) \mathrm{mm}$, where $D$ is the distance between base stations of the GSPG network. Such an error is primarily due to the fact that part of the GSPG baselines uses ground-based base stations (base stations of the State Geodetic Network). The lines at the both ends of which are the stations with force centring have a MSE of about 1-3 $\mathrm{mm}$ with a relative error of about $10^{-7}$. The chain of baselines with force centering goes across the entire network has a length of $63 \mathrm{~km}$.

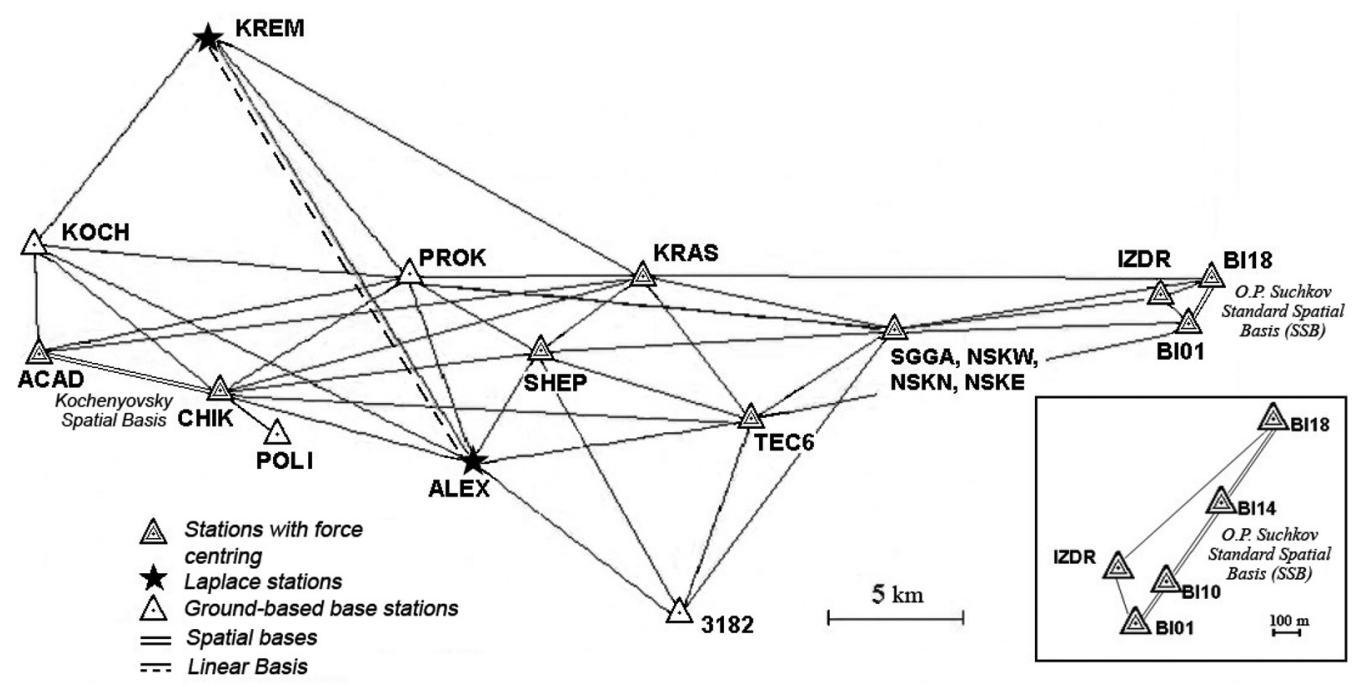

Figure 1. GSPG network and O. P. Suchkov Standard Spatial Basis (SSB) of the SSUGT 
The GSPG network includes three bases (see Figure 1): O. P. Suchkov Standard Spatial Basis with the length of $1104 \mathrm{~m}$, Kochenyovsky Spatial Basis with the length of $8432 \mathrm{~m}$, and Kremlevka-Alekseevka Linear Basis, which is an outer edge in a segment of the State Main Triangulation Network. Optical distance measurements were taken at O. P. Suchkov SSB and Kochenyovsky Spatial Basis; additionally, high-precision distance and height measurements were taken at O. P. Suchkov SSB with a certain periodicity (Antonovich \& Kulikova, 2017).

O. P. Suchkov SSB consists of 22 deep-laid tubular steel pile foundations, in accordance with requirements of Industry standard STO 02570823-19-05 (Federal'noe agentstvo geodezii i kartografii Rossii, FGUP “Tsentral'nyy ordena 'Znak Pocheta' nauchno-issledovatel'skiy institut geodezii, aeros"emki i kartografii im. F. N. Krasovskogo", 2005). Four base stations BI01, BI10, BI14, and BI18 are used for satellite measurements, and results of the measurements are used for metrological certification of GNSS equipment. O. P. Suchkov SSB obtained the Time-unlimited Certificate RU.E.27.007.A No. 25883, stating that O. P. Suchkov SSB registered in the State Register of Measuring Equipment under registration number No. 3317606 and approved for use in the Russian Federation. MSE for O. P. Suchkov SSB intervals measured within the temperature range $-10 \ldots+30{ }^{\circ} \mathrm{C}: \pm 0.1 \mathrm{~mm}$ for the interval 0-192 $\mathrm{m} ; \pm 0.2 \mathrm{~mm}$ for the interval $192-660 \mathrm{~m} ; \pm(0.3+$ $1 \times 10^{-6} \mathrm{D}$ ) for the interval $660-1103 \mathrm{~m}$.

Description of the experiment. To study the possibility of using GNSS receivers with CSACs with an instability of $10^{-11}$ to improve Standard complexes that ensure the uniformity of length measurement, the authors selected a 912-meter-long (BI10-BI18) baseline of O. P. Suchkov SSB to carry out a suite of measurements on October 22, 2017 (Figures 2-3). The selection of a short baseline was stipulat-

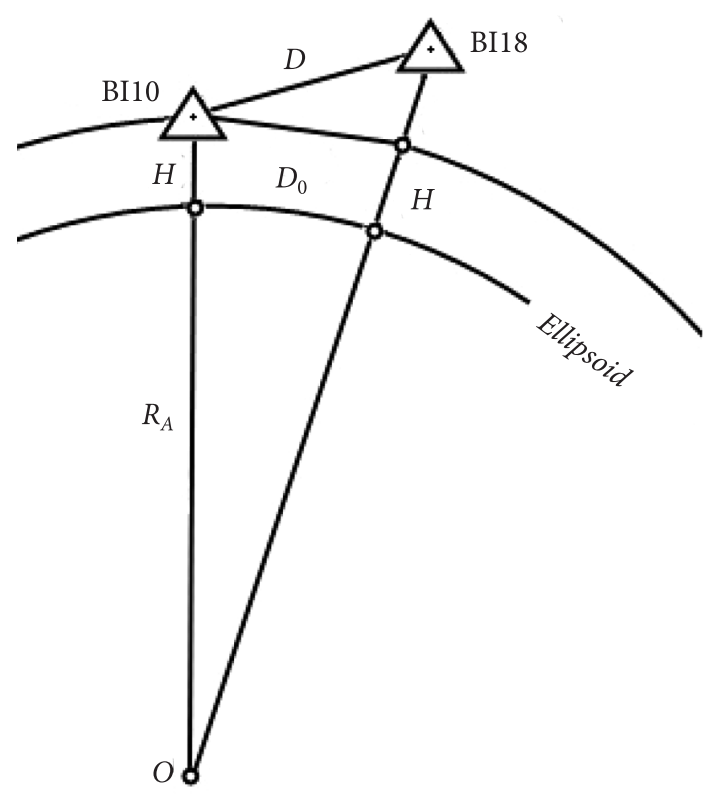

Figure 2. Geometry of O. P. Suchkov SSB in the plane of normal section passing through the line BI10-BI18 ed by the following positive effect: for a short baseline with a small difference of height, the influence of tropospheric and ionospheric errors will be strongly correlated and, therefore, will be eliminated at the stage of formation of double differences, while clock errors do not possess this property.

In total, we carried out two sessions of measurements of two hours' duration each, and each for one different antenna height. The temperature difference in the 4-hour period did not exceed $4{ }^{\circ} \mathrm{C}$, the total number of GLONASS and GPS satellites was no less than 15 .

For measurements at O. P. Suchkov SSB was used a calibration kit consisting of two JAVAD Sigma Q-G3T GNSS receivers with GrAnt G3T antennas. Designed by ZAO RUKNAR rubidium frequency standards of Ch1-1012 type with a relative error of frequency reproduction $\leq 2 \cdot 10^{-11}$ (Ruknar, n.d.) were connected to the external ports of the receivers. Prior to taking measurements, the rubidium frequency standards were calibrated, and their frequency mean square two-sample errors (MSTSE) were determined at the Siberian Scientific Research Institute of Metrology.

Table 1 shows technical parameters of the rubidium frequency standards based on the calibration results obtained using VET 1-19 secondary time and frequency standard (Kopeikin et al., 2016).

Table 1. Technical parameters of rubidium frequency standards used in the experiment

\begin{tabular}{|l|c|c|}
\hline \multirow{2}{*}{ Averaging interval } & \multicolumn{2}{|c|}{ Permissible MSE } \\
\cline { 2 - 3 } & Standard No. 1 & Standard No. 2 \\
\hline 1 second & $1.4 \cdot 10^{-11}$ & $1.4 \cdot 10^{-11}$ \\
\hline 10 seconds & $3.5 \cdot 10^{-12}$ & $3.9 \cdot 10^{-12}$ \\
\hline 100 seconds & $1.2 \cdot 10^{-12}$ & $1.3 \cdot 10^{-12}$ \\
\hline
\end{tabular}

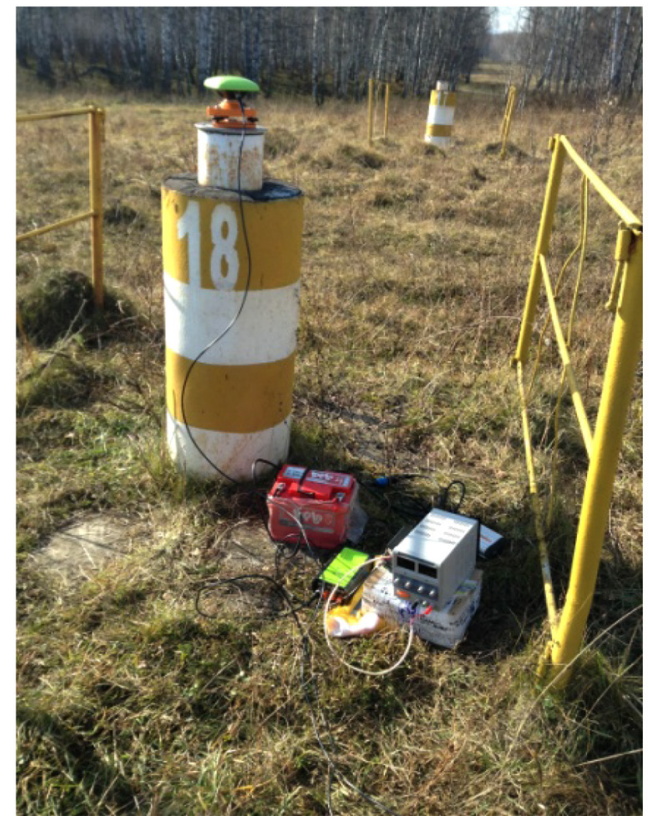

Figure 3. Base station BI18 of O. P. Suchkov SSB with GNSS equipment placed upon it 
Table 2. Results of the experiment

\begin{tabular}{|c|c|c|c|c|c|c|}
\hline \multirow{2}{*}{$\begin{array}{l}\text { Data } \\
\text { source }\end{array}$} & \multirow{2}{*}{$\begin{array}{c}\text { No. } \\
\text { of measurement }\end{array}$} & \multicolumn{2}{|c|}{ Accuracy characteristics } & \multirow{2}{*}{$\begin{array}{c}\text { Slant distance, } \\
D(\mathrm{~m})\end{array}$} & \multicolumn{2}{|c|}{ Estimated accuracy $(\mathrm{mm})$} \\
\hline & & $a$ & $b$ & & $V$ & $M$ \\
\hline Magnet & 1 & 3 & $0.5 \times 10^{-6}$ & 911.7188 & +1.4 & 3.5 \\
\hline Magnet & 2 & 3 & $0.5 \times 10^{-6}$ & 911.7183 & +0.9 & 3.5 \\
\hline Justin & 1 & 3 & $0.5 \times 10^{-6}$ & 911.7175 & +0.1 & 3.5 \\
\hline Justin & 2 & 3 & $0.5 \times 10^{-6}$ & 911.7163 & -1.1 & 3.5 \\
\hline Giodis & 1 & 3 & $0.5 \times 10^{-6}$ & 911.7199 & +2.5 & 3.5 \\
\hline Giodis & 2 & 3 & $0.5 \times 10^{-6}$ & 911.7189 & +1.5 & 3.5 \\
\hline Topaz SP2 & 1 & +1.5 & $2 \times 10^{-6}$ & 911.7189 & +1.5 & 3.3 \\
\hline Topaz SP2 & 2 & +1.5 & $2 \times 10^{-6}$ & 911.7190 & +1.6 & 3.3 \\
\hline GTS601 & 1 & 2 & $2 \times 10^{-6}$ & 911.7188 & +1.4 & 3.8 \\
\hline Trimble 5700 & 1 & 5 & $0.5 \times 10^{-6}$ & 911.7080 & -9.4 & 5.5 \\
\hline
\end{tabular}

\section{Results and discussions}

The GNSS measurements were taken simultaneously using GLONASS and GPS systems and three different software products (SP): Magnet Office Tools, Justin, and Giodis with default settings, and using the precise ephemeris data of the International GNSS Service. Table 2 shows the results of the experiment.

To confirm the experimental results, there, in Table 2, are results of additional linear measurements taken using the following traditional geodetic tools and data obtained during previous experiments: two optical distance meters of Topas SP2 type and a TOPCON GTS601 high performance total station; the results of measurements taken in the year 2000 by Trimble 5700 GNSS receivers without the use of CSACs. The line lengths measured by traditional geodetic instruments were taken from the paper by V. A. Seredovich and I. O. Suchkov (Seredovich \& Suchkov, 2014).

The measured values of slant distances $D$ were compared with the certified value $D^{\text {cert }}$. for BI10-BI18 baseline of O. P. Suchkov SSB. The certified value $D^{\text {cert }}$ for BI10BI18 baseline of O. P. Suchkov SSB equals to $911.7174 \mathrm{~m}$ and is estimated with an MSE of $0.7 \mathrm{~mm}$ with a probability of 0.95 . For each measured value of the slant distance $D$, the a priori mean square error $M$ is calculated by the following formula:

$$
M=a+b \cdot D
$$

where $a$ and $b$ are the certified accuracy values of GNSS equipment with quartz clocks and traditional geodetic tools, respectively; $D$ is the distance between base stations.

When comparing the results, it was taken into account that the distances obtained by traditional geodetic tools were given in the form of horizontal distances $D_{0}$, that is, they are reduced to a horizontal plane passing through the initial point of the baseline (Figure 2) (Antonovich \& Strukov, 2010):

$$
D_{0}=\sqrt{D^{2}-\Delta H^{2}-2 D^{2} \Delta H /\left(R_{A}+H\right)},
$$

where $\Delta H$ is the difference between the geodesic heights of the basis endpoints, $R_{\mathrm{A}}$ is the radius of the normal section of the ellipsoid in the azimuth of the basis $A$ (Figure 2). A change in the station error near to the baseline was not taken into account.

As a result of the comparison, the deviations $V$ between measured values of the slant distances $D$ and their certified values $D^{\text {cert }}$. Based on the comparison results, the mean deviation between measured values of the slant distances $D$ obtained by GNSS receivers connected to CSAC and their certified value $D^{\text {cert }}$. varied in the range of $0.1-$ $2.5 \mathrm{~mm}$, with the average value of $0.9 \mathrm{~mm}$. The mean deviation between the values obtained using GNSS geodetic receivers not connected to CSAC and their certified value made up $9.4 \mathrm{~mm}$, which is almost 4 times greater than the maximum deviation value between the slant distance $D$ measured by GNSS receivers connected to CSAC and its certified value $D^{\text {cert. }}$.

\section{Conclusions}

As a result of the research, a successful experiment was performed to measure a short GNSS baseline by receivers equipped with small CSAC with instability of the order of $10^{-11}$ at the Reference Polygon SGUGiT.

An analysis of the experimental results showed that the mean deviation between measured values of the slant distances $D$ obtained by GNSS receivers connected to CSAC and their certified value $D^{\text {cert }}$. varied in the range of $0.1-2.5 \mathrm{~mm}$, with the average value of $0.9 \mathrm{~mm}$. The mean deviation between the values obtained using GNSS geodetic receivers not connected to CSAC and their certified value made up $9.4 \mathrm{~mm}$.

The obtained experimental results suggest that substitution of quartz frequency generators with temperature compensation used in geodetic GNSS receivers for CSAC in a calibration kit consisting of two JAVAD Sigma Q-G3T GNSS receivers with GrAnt G3T antennas allows increasing accuracy and reliability of short baselines measurement results. Authors believe that it is reasonable to 
develop a technique for creating reference baselines with a reproduction error of unit length of about $1 \mathrm{~mm}$ per $1 \mathrm{~km}$.

\section{Recommendations}

A promising area for improving the standard complexes that ensure the uniformity of length measurement is the use of Leica Nova TS60 I total station, which, according to the developers, provides measurement of line lengths with an error of $0.6 \mathrm{~mm}$ at distances up to $1 \mathrm{~km}$ (Firma G.F.K., n.d.).

Thus, the experiment described in this article opens up new promising research areas on application of CSAC in such fields of science as metrological support of geodetic tools, geodesy, etc.

\section{Acknowledgements}

The authors are grateful for the assistance provided in the experiment by: Tolstikov A. S., Dr. Tech. Sci., Head of Division No. 8 of the Siberian Research Institute of Metrology; Alexandrov A .L, Director of ZAO RUKNAR; Maksimenko V. V., Head of the Sales Department of Satellite and Navigation Equipment of OOO UGT-Holding.

\section{References}

Antonovich, K. M., \& Kosarev, N. S. (2012). Metod kontrolya kodovykh i fazovykh psevdodal'nostey v prostranstve koordinat [Control method for code and phase pseudoranges in the coordinate space]. Izvestiyaa vuzov, Geodeziya $i$ aerofotos'yomka, 2(1), 11-15.

Antonovich, K. M., \& Kulikova, L. G. (2017). Etalonnomu prostranstvennomu poligonu SGUGiT 20 let. [The spatial reference proving ground of the Siberian State University of geosystems and technologies is 20 years old]. Proc. of Interekspo and Geo-Sibir' Congress, 1(2), 107-112.

Antonovich, K. M., Kosarev, N. S., \& Lipatnikov, L. A. (2014). Kontrol' fazovykh izmereniy GNSS-priyemnika s atomnymi chasami [Control of phase measurements of a GNSS receiver with atomic clock]. Vestnik SGGA, 3(27), 3-21.

Antonovich, K. M., \& Strukov, A. A. (2010). Sravneniye rezultatov lineynykh izmereniy, vypolnennykh sputnikovymi i traditsionnymi metodami geodezii [Comparison of Results of Linear Measurements Performed by Satellite- and Traditional Methods of Geodesy]. Geo-Sibir' Journal, 1(3), 38-42.

Antonovich, K. M., \& Kosarev, N. S. (2014, April 14-15). Future challenges of the small atomic oscillators used in GNSS monitoring systems for structures and natural objects. In International Workshop workshop "Integration of point and area-wise geodetic monitoring for structures and natural objects", SGGA, Novosibirsk, Russian Federation (pp. 220-222).

Beard, K., \& Senior, R. (2017). Clocks. In Springer handbook of global navigation satellite systems (pp 121-164). Springer. https://doi.org/10.1007/978-3-319-42928-1_5

Chan, F. C., Joerger, M., Khanafseh, S., Pervan, B., \& Jakubov, O. (2014). Reducing the Jitters: How a Chip-Scale Atomic Clock can help mitigate broadband interference. GPS World, 5, 4450.

Denisenko, O. V., Sil'vestrov, I. S., Fedotov, V. N., Kaverin, A. M., Pecheritsa, D. S., Voronov, V. L., Ryabov, I. V., \& Zavgorodniy, A. S. (2016). Razvitiye sredstv metrologicheskogo obe- specheniya kak osnova dlya povysheniya tochnostnykh kharakteristik sistemy GLONASS [Development of metrological support tools as a basis for increasing the accuracy characteristics of GLONASS system]. Mir izmereniy Journal, 3, 13-17.

Enric, F., Calero, D., \& Parés, M. E. (2017). CSAC Characterization and its impact on GNSS Clock Augmentation Performance. Sensors, 17(2), 370. https://doi.org/10.3390/s17020370

Federal'nyy Zakon No. 102. "Ob obespechenii yedinstva izmereniy" [Federal Law No. 102 "On ensuring the uniformity of measurements", adopted by the State Duma on June 11, 2008] (2008). Retrieved from http://www.consultant.ru/document/ cons_doc_LAW_77904/

Federal'noe agentstvo geodezii i kartografii Rossii, FGUP “Tsentral'nyy ordena 'Znak Pocheta' nauchno-issledovatel'skiy institut geodezii, aeros"emki i kartografii im. F. N. Krasovskogo". (2005). Bazisy lineynyye etalonnyye. Obshchiye tekhnicheskiye trebovaniya (STO 02570823-19-05). [Linear Standard Bases. General Technical Requirements (STO 02570823-1905)]. Moscow: TSNIIGAiK. $42 \mathrm{p}$.

Firma G.F.K. (n.d.). Leica Nova TS60 I. Retrieved from https:// www.gfk-leica.ru/katalog/taheometry/taheometry_leica_ serii_nova/nova_ts60i_05/

Karpik, A. P., Seredovich, V. A., Antonovich, K. M., \& Kulikova, L. G. (2010). Etalonnyy geodezicheskiy poligon SGGA unikal'nyy ob'yekt sistemy obrazovaniya RF [The reference geodetic range of SSGA is a unique object of the RF education system]. Geo-Siberia Journal, 5(2), 180-184.

Kitching, J. (2007). Time for a better receiver: Chip-Scale Atomic frequency. GPS World, 11, 52-57.

Kopeikin, S. M., Kanushin, V. F, Karpik, A. P., Tolstikov, A. S., Gienko, E. G., Goldobin D. N., Kosarev, N. S., Ganagina, I. G., Mazurova, E. M., Karaush, A. A., \& Hanikova, E. A. (2016). Chronometric measurement of orthometric height differences by means of atomic clocks. Gravitation and Cosmology, 22(3), 234-244.

https://doi.org/10.1134/S0202289316030099

Krawinkel, T., \& Schön, S. (2015, September 14-18). Benefits of Chip Scale Atomic Clocks in GNSS applications. In Proceedings of the 28th International Technical Meeting of The Satellite Division of the Institute of Navigation (ION), Tampa, FL, USA, (pp. 2867-2874).

Programma "Tsifrovaya ekonomika Rossiyskoy Federatsii" [The program "Digital Economy of the Russian Federation"]. Approved by the order of the Government of the Russian Federation of July 28, 2017. (2017). Retrieved from http://static. government.ru/media/files/9gFM4FHj4PsB79I5v7yLVuPgu4 bvR7M0.pdf/

Ruknar. (n.d.). Standart chastoty rubidiyevyy CH1-1012 [Rubidium Frequency Standard Ch1-1012]. Retrieved from http:// ruknar.ru/ prod/datach1-1012.pdf

Seredovich, V. A., \& Suchkov, I. O. (2014). Ob opyte issledovaniya sposoba izmereniya rasstoyaniy v kombinatsiyakh na etalonnom bazise [On experience of studying different method of measuring distances based on a standard basis]. Izvestiya vysshikh uchebnykh zavedeniy. Geodeziya i aerofotos'yemka Journal, S4, 62-66.

Shchipunov, A. N., Tatarenkov, V. M., Denisenko, O. V., Sil'vestrov, I. S., Fedotov, V. N., Vasil'ev, M. Yu., \& Sokolov, D. A. (2015). A set of standards for support of the uniformity of measurements of length in the range above $24 \mathrm{~m}$ : current state and prospects for further development. Measurement Techniques, 57(11), 1228-1232. https://doi.org/10.1007/s11018-015-0610-9 
Shkel, A. M. (2011). Microtechnology comes of age. GPS World, 9, 11-15.

Sil'vestrov, I. S., Mazurkevich, A. V., Vernitskiy, D. M., Sokolov, D. A., \& Golub, D. A. (2016). Gosudarstvennyy pervichnyy spetsial'nyy etalon yedinitsy dliny v diapazone ot $24 \mathrm{~m}$ do $4000 \mathrm{~km}$ [State primary special standard of length units in the range from $24 \mathrm{~m}$ to $4000 \mathrm{~km}$ ]. Geoprofi: nauchno-tekhnicheskiy zhurnal po geodezii, kartografii i navigatsii, 2, 21-25.

Surnin, Y. V. (2004). Polevoy astrogravigeodezicheskiy etalon dlya metrologicheskikh ispytaniy geodezicheskoy apparatury [Field astro-gravi-geodesic standard for metrological testing of geodetic equipment]. Izmeritel'naya tekhnika Journal, 9, 3-7. 